\title{
Sector process and episodes of change: an analysis of daily newspapers in The Netherlands
}

\author{
Harry Sminia* \\ Department of Administrative and Communication Sciences, Faculty of Social and Cultural \\ Sciences, Vrije Universiteit, Amsterdam, The Netherlands
}

This paper presents a framework for analysing sector change based on the theory of social becoming. It is argued that:

- There are four levels of social structure that characterize a sector. These are the opportunity level, the normative level, the ideal level and the interactional level.

- Change is paired with contradiction with regard to one or more of these four levels of social structure.

- Contradictions occur in a successive collection of episodes, with an episode of change defined as a sequence of events during which contradiction comes to the surface and is acted upon.

- This article presents two episodes of change that occurred in the Dutch daily newspaper sector over the period 1991-1997 with each episode characterized in terms of the four levels of social structure.

Copyright $@ 2002$ John Wiley \& Sons, Ltd.

\section{Introduction}

Within strategic management, the analysis of the environment has always been a fundamental part of management deliberations. Initially in strategy theory, the environment was perceived as the focus of opportunities and threats to the organization. Porter (1981) was one of the most prominent strategy pioneers that sought to provide the discipline with a management theory for external analysis. The five-forces model together with contributions from strategic group theory has been an important conceptualization of

* Correspondence to: Dr Harry Sminia, Department of Administrative and Communication Sciences DBL 859, Faculty of Social and Cultural Sciences, Vrije Universiteit, De Boelelaan 1081c, 1081 HV Amsterdam, The Netherlands.

E-mail: h.sminia@mdw.vu.nl the operating environment for several years. Equally, contributions from marketing have provided the strategist with a distinct vocabulary for analysing the environment as well (Biggadike, 1981). A recent contribution is the resource-based view. Here, the focus is on factor markets that provide the firm with the resources that allow for a sustainable competitive advantage (Barney, 1986).

These three approaches in the strategy field have been principally derived from economics. Parallel to these developments, authors building more on the social sciences have made contributions to a different and more complex understanding of the environment. For instance, groups of firms active in the same industry create cognitive communities (Porac et al., 1989), share certain strategic recipes (Spender, 1989) or are 
characterized by a particular strategic wisdom (Melin, 1989). This has led to some debate with regard to the question why strategic groups exist at all (Reger and Huff, 1993). Is it because, independent of the firms concerned, certain industrial organization parameters are what they are and independent of managerial action and interpretation? Or is it perhaps because managers in particular firms interpret the industry in a certain manner and act accordingly, thus creating strategic groups as a consequence of their own actions? The latter position is echoed by those researchers that think the environment is subject to processes of institutionalization, working at for instance, the level of a sector (Child and Smith, 1987; Räsänen and Whipp, 1992; Smith et al., 1990) or a business system (Whitley, 1992).

This paper introduces an approach that sees sector change as a process of institutionalization. Accordingly, the theory of social becoming (Sztompka, 1991) is discussed. It is this theory that leads to an analysis of sector process as a process of continuity interlaced with distinct episodes of change. These episodes of change are thought to occur around specific controversies between actors that are part of the sector. This approach is then applied to the Dutch daily newspaper sector. Two episodes of change have been identified with regard to the 1991-1997 period. These two episodes have been labelled 'diminishing market penetration' and 'the rise of commercial broadcasting'. In both instances a

\section{Two episodes of change have been identified in the Dutch daily newspaper sector}

certain amount of sector change could be observed. The analysis is based on case material, consisting of the annual reports of the Dutch major publishers as well as their representative organization. How the analysis was done will be described in more detail below. First, an outline of the theory of social becoming as applied to sector change is given.

\section{Institutionalization as a process of social becoming}

In terms of the writings of Van de Ven and Scott Poole (1995), the theory of social becoming (Sztompka, 1991) is a dialectic process theory. Institutionalization is seen as a constant interplay between agency and structure. Structure shapes, and is shaped by, sequences of manifested action. Actors perform and behave within the bounds of structure but also find ways to defy it. Continuity is the outcome of the process whenever agency remains within the bounds of the existing structure. When this happens, the process simply repeats itself. Change occurs when actions go beyond given bounds and effectively elements of social structure are changed. Consequently leading to new potential agency, with the resulting process taking a new turn. It is a line of reasoning that is very similar to Giddens' (1979) structuration theory.

To Sztompka (1991), there are four levels of social structure. The normative level refers to the network of rules, norms, values and institutions prescribing the proper, expected conduct, and proscribing the wrong, forbidden modes of buman action. With regard to sector process, this resembles ideas from the new institutionalism approach (Powell and DiMaggio, 1991). The ideal level concerns the network of ideas, beliefs, images and convictions about reality. This is something that has been identified by various authors when they investigated commonly held beliefs about the nature of a sector or industry (e.g. Porac et al., 1989; Reger and Huff, 1993; Spender, 1989). This is what Child and Smith (1987) call the cognitive arena. The third level is the interactional network. These are the actual relationships that exist within a network but also there are possibilities and impossibilities for interaction outside existing relationships (Johansson and Mattsson, 
1987). This level resembles what Child and Smith (1987) have dubbed the collaborative network. The fourth level is the opportunity level. This level refers to the vested interests and variable access to valued resources or facilities, which both constitute the power configuration. This level can be associated with the interdependencies as described in the resource-dependence approach (Pfeffer and Salancik, 1978). Interests and power are also main building blocks of the stakeholder approach in strategic management (Freeman, 1984). Furthermore, much that has come forward as a consequence of reasoning in the strategy field that have been derived from economics, describe the opportunities of the firm. As such, this level has much to do with Child and Smith's (1987) objective conditions.

The proposition here is to see change as a manifestation of latent contradictions that are apparent in the social structure. These latent contradictions can surface in either one or more of the levels of social structure mentioned above. With regard to the normative level, contradiction occurs whenever an issue arises about the norms and values concerning a particular situation. This happens if the behaviour of a certain actor is not considered legitimate by some of the other relevant actors and they object to such actions. At the ideal level, contradiction manifests itself through conflict over the interpretation of the situation. This happens whenever there are rival interpretations of the situation that lead to ineffective activities. Contradiction at the interactional level is manifest whenever a certain relationship becomes inoperative. Conflict happens here if one actor terminates a relationship or outside circumstances makes actual interaction impossible while at least one of the actors concerned wish to continue the relationship. Finally at the opportunity level, contradiction manifests itself as pure conflict of interests. This happens when activities of one actor impinge on the opportunities of another.

When it comes to applying the theory of social becoming to sector process to identify continuity and change, it reduces to identifying the actors concerned and looking for controversies and contradictions with regard to the four levels of social structure. The proposition here is to look at these contradictions and controversies as occurring in a successive collection of episodes.

An episode of change is defined here as a sequence of events during which contradiction comes to the surface and is acted upon.

Each of these episodes can be characterized in terms of which of the four levels of social structure are affected. Taking all of this together, sector process is seen as a combination of continuity and change. Continuity is the case whenever enough agreement between actors has been established to foster enduring and stable interaction. Change and adaptation however, comes in distinguishable episodes during which contradiction comes to the surface and is acted upon. This can have two results. First, part of the social structure characterizing the sector is changed, or second, after a period of ambiguity, the existing social structure is again reconfirmed. This line of thinking has been utilized to analyse continuity and change in the Dutch daily newspaper sector over the 1991-1997 period. Both the sector as well as the way this analysis was done will be introduced next.

\section{The Dutch daily newspaper sector 1991-1997}

The Dutch daily newspaper sector contains a number of firms that are all members of the Dutch Newspaper Association (NDP). Most of these newspaper publishers are part of larger publishing groups. The analysis presented here is based on the annual reports of those publishing groups that are listed on the Amsterdam Stock Exchange. These groups include Elsevier (later Reed Elsevier), the De Telegraaf holding company, Perscombinatie (later PCM), VNU, and Wegener (later Wegener Arcade). These data sources are supplemented with the NDP annual reports. Because of their status, the annual reports 
are publicly available. These organizations had approximately an $80 \%$ market share in newspaper circulation in the period 1991-1997. As a result, a small number of newspaper publishers appear only indirectly in the data, as they are mentioned in the annual reports of their listed competitors or in the NDP annual reports.

To apply the theory of social becoming to the Dutch daily newspaper sector, the texts were coded by categories of actors and events. It was necessary to assess the actors who appeared to be part of this sector in order to identify specific events as the act of a particular actor. The events, in turn, were found to allow for a grouping together to indicate distinct episodes of change. Two episodes of change are reported here. Both episodes have been linked to a particular controversy. The first episode was labelled 'Diminishing Market Penetration'. This episode was marked by tension in the market-exchange relationship between newspaper publishers and readers. The second episode, dealing with the 'Rise of Commercial Broadcasting' was characterized by a strenuously competitive relationship between newspaper publishers and broadcasting companies, especially with regard to advertising.

What follows next are separate descriptions of these two episodes of change. The events making up the two episodes are part of the account. Each episode then is characterized in terms of continuity and change with regard to the four levels of social structure. What will be indicated is if change occurs and which of the levels are affected.

\section{Diminisbing market penetration}

In 1991 newspaper circulation figures dropped for the first time since 1985, subsequently stabilizing over the 1991-1997 period. In $1988,82.1 \%$ of Dutch households had a newspaper subscription. In 1997, this was down to $73.5 \%$. There was little indication this trend of diminishing market penetration was leading to a general sense of urgency among newspaper company management as such. However, individual newspapers did react to changes in their own circulation figures on an ad boc basis. Especially publishers of regional newspapers have embarked on major reorganizations that were partly the result of disappointing circulation figures combined with decreasing advertising revenues. Because newspaper publishers had agreed not to compete on price (a number of price agreements exist, but these are under siege because of impending legislation, see below), the only way to improve a newspaper's competitive position is by reducing costs and/or by improving quality.

Since 1970, the Dutch newspaper industry has been subject to a number of special agreements that prevented individual publishers

\section{Since 1970, the Dutch newspaper industry bas been subject to a number of special agreements}

from starting a price war. The Dutch government tolerated the newspaper publishers protecting themselves from competing on price in order to concentrate on editorial variety and quality and to be guaranteed a reasonable return on their investments. As such, the diversity of the written press was perpetuated, which in turn was considered essential for a democratic society. However, in 1991, the Ministry of Economic Affairs reconsidered the rules of fair competition, resulting in a proposal to declare every horizontal price agreement in the Netherlands non-binding. The new ruling would provide a system of exceptions to be granted after the parties concerned had filed a request.

The NDP immediately appealed against this proposal, arguing that price fixing in the newspaper industry should not be an exception but a rule in itself, given the essential role of the written press in a democratic 
society. Nevertheless, the ruling was issued in 1993 and accepted by Parliament, on the assurance that the newspaper industry could expect to be treated as an exception. The NDP immediately filed an appeal. As a result, the minister proposed a ruling that would declare vertical price fixing in the newspaper industry to be exempt from the new Competition Bill until 2003, when a new decision was to be made. This cleared the way for the Competition Act to become effective on 1 January 1998.

Looking at the relationship between readers and newspaper publishers, it seems that the interactional level is causing a problem. The group of readers with whom full interaction takes place is diminishing year by year in relative terms. Attempts to raise journalistic quality apparently had no effect here. This trend affects the nature of the competition between individual newspapers. It has increased, especially in terms of journalistic quality, putting a strain on the opportunity level as market growth occurs at the expense of competing newspapers. In real terms, the opportunities for newspaper publishers are diminishing, as more investment is needed to maintain or improve journalistic quality while readership is declining.

With regard to the normative level, price wars were prevented due to the existence of price agreements. Nevertheless, newspaper companies experienced growing difficulty in legitimizing this particular norm with regard to not competing on price but only on journalistic quality. The Dutch government seemed to favour the norm of free competition more and more, while becoming less convinced of the special place of the written press in a democratic society and the need to safeguard its diversity by preventing price competition. This might begin to affect the nature of the competitive relationship between newspapers, opening up the possibility of competition on both quality and price. As far as this episode is concerned, structural sector change is taking place, encompassing the interactional, opportunity, and normative levels of the social structure of the Dutch daily newspaper sector.

\section{The rise of commercial broadcasting}

Newspaper publishers also had to deal with intensifying competition from broadcasting organizations. Until 1988, broadcasting in

\section{Newspaper publishers \\ bad to deal with intensifying competition from broadcasting organizations}

the Netherlands was regulated by way of a public broadcasting system funded by a compulsory license fee for every television and radio owner. As a consequence, it was illegal for anyone in the Netherlands to broadcast anything outside the PBS scheme.

Because of municipal policies abolishing roof antennas, the majority of Dutch households were on cable. In the meantime, satellite TV channels were becoming available at moderate prices. A few shrewd businessmen tried to exploit a loophole in the Dutch Media Act by launching a commercial TV channel aimed at the Dutch market, but under a Luxembourg license. This channel would be receivable via a satellite dish and transmitted by cable. By 1991, this initiative resulted in the RTL4 TV channel, gaining a substantial market share alongside the three Dutch PBS TV channels. With a full-fledged commercial TV channel coexisting alongside the PBS system, both publishers and the PBS had to deal with a form of competition that had previously not prevailed. The publisher VNU had reacted the most rapidly, having secured a $38 \%$ share in RTL4.

The Dutch government took note of the new situation and changed elements of the Media Act from 1 January 1992. In 1992, 
Perscombinatie entered a so-called publicprivate partnership with the Amsterdam municipal cable company to launch a local commercial TV station called AT5. In the same year, the holding company of De Telegraaf inaugurated the local commercial radio station Radio Amsterdam. It also announced its ambition to participate in a national commercial TV station. VNU, naturally, held on to its stake in RTL4. Wegener also wanted to participate in a national commercial TV station but initially chose to do nothing, viewing the conditions under which it would be obliged to venture into commercial broadcasting at the time as too restrictive.

On 24 April 1996, following some delay, the Media Act was eventually revised, lifting the ban on commercial regional broadcasting but upholding the principle of public broadcasting and its non-involvement in third-party profits. Nevertheless, the way the new Act was formulated did not exclude every form of cooperation between public broadcasting organizations and private companies. In 1996, PCM, as the successor of Perscombinatie, under the new rules of the 1996 revised Media Act, became the full owner of the TV production company OBA which produced AT5 programmes, while AT5 continued to be a public local broadcasting organization, licensed by the Municipality of Amsterdam. In this way, PCM officially became the supplier of TV programmes for AT5, resulting in a situation where OBA was making the profits while AT5 was doing the broadcasting. In this way, AT5 had effectively become a PCM company. A number of public-private partnerships in regional broadcasting similar to the AT5 deal were made in the Rotterdam area, and in the Provinces of South Holland, North Brabant, and Limburg, involving PCM, the De Telegraaf holding company, VNU and Wegener Arcade.

Meanwhile, both the De Telegraaf holding company and Wegener were seeking further opportunities to enter the national commercial television business as well. In 1995, the record company Arcade had launched the fifth and sixth commercial TV stations under the names TMF and TV10 respectively. Arcade merged with publishing group Wegener in 1996, which meant Wegener had also fulfilled its ambition with regard to national commercial television. The same year also saw the De Telegraaf holding company taking its turn as it acquired a $30 \%$ stake in the newly-launched seventh commercial TV venture, SBS6. From then on, Dutch viewers had the luxury of choice between nine national TV channels (not counting foreign TV channels also transmitted by the cable companies), and at least one regional station.

This was a mixed blessing for advertisers. Competition between the various channels certainly exercised a favourable effect on advertising rates. On the other hand, because Dutch viewers were dispersed over more channels, advertisers had to buy more advertising time to reach the same number of consumers as they had done a few years previously. Meanwhile all newspaper publishers streamlined their commercial and marketing departments in an attempt to try to offer better service to their advertising clients.

In the meantime, cable companies had reached the limits of their transmission capacity. Wegener's TV10 was suffering in particular, not being transmitted across the entire country. Capacity was also one of the main problems leading to the collapse of a dedicated sports TV channel that failed spectacularly in 1996. Sport7 was a joint venture between the Royal Dutch Football Association and a number of investors including the De Telegraaf holding company. The venture lasted only a few months during which it had difficulties with, among other things, viewing rates and cable access.

From 1995 onwards, advertisers' enthusiasm for TV commercials was waning on two counts. First, Dutch viewers were becoming increasingly irritated by TV commercials and tended to turn to a different channel more often whenever a commercial began. As a consequence, TV commercials were being broadcast but not watched. Second, because of the ever-growing number of TV channels, advertisers were questioning the 
coverage of TV advertising. As stated above, commercials needed to be broadcast more often to reach the same number of people. Advertisers started to realize that newspaper advertising offered them a better deal. On the whole, revenues in commercial television were under pressure. HMG had to institute a number of cost-cutting measures in 1996 and 1997, while VNU was considering selling its stake in the company. TV10 was also struggling under the ownership of Wegener Arcade. Some of the shares in this channel were sold in 1996, and Wegener Arcade ditched it entirely in 1997.

Reflecting on this episode, one of the remarkable aspects is the number of new actors who attempted to become part of the sector. This put pressure on the rivalry between the newspaper publishers and these new broadcasting companies, as well as on competition between the broadcasting companies themselves. This growing rivalry for advertising guilders, initially during an economic downturn, naturally led to increasing antagonism with regard to the opportunity level. Publishers' reactions were twofold. At the level of the publishing groups, one tried to secure holdings in broadcasting companies in an attempt to retain advertising revenues, and eventually all succeeded in one way or another. At the level of the newspaper subsidiaries, one tried to compete head-on with the broadcasting companies to limit the loss of market share. In the meantime, the government was involved in redefining the normative level. On the one hand, they had to adapt to practices that could not be reversed. On the other, they wanted to conserve the PBS system as a legitimate form of broadcasting, deserving of government protection in a market becoming ever more competitive.

Another additional effect of interest in this context concerns the relationship between the broadcasting companies and the cable companies. It is the interactional level that takes centre-stage here. The commercial TV channels and initially the radio channels could only be transmitted by cable because the airwaves were reserved for the PBS channels. All the new commercial channels had to compete for places on the cable network, which in turn, suffered from a limited transmission capacity. Two TV channels in particular suffered. These were the abortive dedicated sports TV channel Sport 7 , backed by the De Telegraaf holding company, and Wegener Arcade's TV10. Their failure loomed when they were only available to viewers on a limited basis, with a number of cable companies not transmitting them. Limitations in the possibilities of actual interaction could apparently not be overcome.

To sum up, this episode saw the emergence of a number of additional actors. By 1997 broadcasting companies that had not existed before 1991 had become part of the sector. This in turn affected the opportunity level in two ways. At the level of the newspaper publishers, competition between these publishers and the broadcasting companies over advertising revenues increased. At the level of the publishing groups however, the rise of commercial broadcasting was being accommodated by securing stakes in these new ventures. At the normative and interactional levels, matters appeared to have largely returned to the old order. With regard to the normative level, the special position of the PBS channels as defined in the Media Act remained part of the equation, although legislation was changed to accommodate the new commercial broadcasting companies. What also remained were limitations on interaction possibilities inherent in the capacity of the cable network.

\section{Discussion and conclusions}

Is this a worthwhile attempt to uncover continuity and change? Does it have a bearing on strategy theory and analysis? A deliberate departure from mainstream reasoning in strategic management has led to an understanding of the environment as a process of institutionalization instead. The theory of social becoming was put forward as a dialectic process theory. The more common lines of thought in strategic management that were derived from economics can find a place at 
the opportunity level. Alongside this level, a sector can also be characterised in terms of a normative level, an ideal level, and an interactional level. Continuity is the case when the process repeats itself. Actors act within the bounds of the existing social structure. Change can occur in distinct episodes through controversies that are a result of a manifestation of latent contradictions in the existing social structure.

The Dutch daily newspaper sector was analysed with this conceptualization of sector process in mind. Two episodes are described here, with each characterized in terms of the four levels of social structure. Both episodes could be traced back to controversies between actors that are part of the sector. This, in turn, opens up the possibility for research that uses contradiction as its point of departure. It urges analysts to open their eyes to latent contradictions and the possibility of the manifestation of these contradictions in a controversy. As these controversies are linked with episodes of change, consequently strategy research and analysis becomes more focused on dealing with change.

It also urges the analyst to look further than just those parameters, which have been derived from economics. As has stated above, these parameters have found a place at the opportunity level. Adding the normative, ideal, and interactional levels brings within reach some of the concepts typical to the social sciences, such as legitimacy, interpretation, interaction and a more refined understanding power. It may even persuade top management to formulate strategies dealing with a wider set of issues than just the competitive position in the firm's economic terms.

\section{Biographical note}

Dr Harry Sminia is Assistant Professor of Strategic Management at the Vrije Universiteit, Department of Administrative and Communication Sciences, Faculty of Social and Cultural Sciences, Amsterdam, The Netherlands.

\section{References}

Barney JB. 1986. Strategic factor markets: expectations, luck, and business strategy. Management Science 32: 1231-1241.

Biggadike ER. 1981. The contribution of marketing to strategic management. Academy of Management Review 6: 621-632.

Child J, Smith C. 1987. The context and process of organizational transformation - Cadbury Limited in its sector. Journal of Management Studies 24: 565-593.

Freeman RE. 1984. Strategic Management: A Stakebolder Approach. Pitman: Boston, MA.

Giddens A. 1979. Central Problems In Social Theory: Action, Structure and Contradiction in Social Analysis. Macmillan: Basingstoke.

Johanson J, Mattsson L-G. 1987. Inter-organizational relations in industrial systems: a network approach compared with the transaction-cost approach. International Studies of Management and Organization 17: 34-48.

Melin L. 1989. The field-of-force metaphor. In Advances in International Marketing (vol. 3), Johansson I, Hallén L (eds). JAI Press: Greenwich, CT; 161-179.

Pfeffer J, Salancik GR. 1978. The External Control of Organizations: A Resource Dependence Perspective. Harper \& Row: New York.

Porac JF, Thomas H, Baden-Fuller C. 1989. Competitive groups as cognitive communities: the case of the Scottish knitwear manufacturers. Journal of Management Studies 26: 397-416.

Porter ME. 1981. The contribution of industrial organization to strategic management. Academy of Management Review 6: 609-620.

Powell WW, DiMaggio PJ (eds). 1991. The New Institutionalism in Organizational Analysis. University of Chicago Press: Chicago, IL.

Räsänen K, Whipp R. 1992. National business recipes: a sector perspective. In European Business Systems: Firms and Markets in Their National Contexts, Whitley RD (ed.). Sage: London; 46-60.

Reger RK, Huff AS. 1993. Strategic groups: a cognitive perspective. Strategic Management Journal 14: 103-124.

Smith C, Child J, Rowlinson M. 1990. Reshaping Work: The Cadbury Experience. Cambridge University Press: Cambridge.

Spender J-C. 1989. Industry Recipes: An Inquiry into the Nature and Sources of Managerial Judgement. Basil Blackwell: Oxford. 
Sztompka P. 1991. Society in Action: The Theory of Social Becoming. Polity Press: Cambridge.

Van de Ven AH, Scott Poole M. 1995. Explaining development and change in organizations. Academy of Management Review 20: 510-540.
Whitley RD. 1992. Societies, firms and markets: the social structuring of business systems. In European Business Systems: Firms and Markets in Their National Contexts, Whitley RD (ed.). Sage: London; 5-45. 